\title{
DYNAMICS AND IMPACTING FACTORS OF ICE REGIMES IN LATVIA INLAND AND COASTAL WATERS
}

\author{
Māris Kḷaviṇš\# , Zanita Avotniece, and Valērijs Rodinovs \\ Faculty of Geographical and Earth Sciences, University of Latvia, Raina bulv. 19, LV-1586, Rīga, LATVIA \\ maris.klavins@lu.Iv \\ \# Corresponding author
}

Contributed by Māris Kḷaviṇš

\begin{abstract}
The sea ice regime is considered to be a sensitive indicator of climate change. This study investigates long-term changes in the ice regimes of the Gulf of Riga along the coast of Latvia in comparison with those of inland waters. The ice regime of the studied region indicates the impact of climate change related to increasing air and sea water temperatures. Ice cover duration on both the sea and inland waters has decreased during recent decades. In addition, long-term records on ice break in the studied region exhibit a pattern of periodic changes in the intensity of ice regime, while trends of the sea ice regime are not consistent between periods of time. Alternating mild and severe winters also occur. The ice regime was shown to be strongly influenced by large-scale atmospheric circulation processes over the North Atlantic, as indicated by close correlation with the North Atlantic Oscillation index.
\end{abstract}

Key words: ice regime, coastal waters, large-scale atmospheric circulation, climate change.

\section{INTRODUCTION}

Records of the dates of ice freeze-up and break-up are good indicators to assess inter-annual and seasonal climate variability, especially in relation to long-term climate change (Beltaos and Burrell, 2003; Johannessen et al., 2004; Saucier et al., 2004; Laidre and Jorgensen, 2005; Granskog et al., 2006; Sooaar and Jaagus, 2007; Sarauskiene and Jurgelenaite 2008). There are three major reasons for studying sea ice regimes: a) the calendar dates of formation and thawing of ice cover have been recorded for a long period, b) ice conditions are sensitive and reliable indicators of climate, and c) sea and coastal ice regimes affect ship transport, fishery, and other aspects of the economy (Takács and Kern, 2015).

Temperature change and ice regimes have been observed to be related with the North Atlantic Oscillation (NAO) pattern (Hurrell and van Loon, 1997; Osborn et al., 1999) of large-scale anomalies in North Atlantic atmospheric circulation. Similarly, Southern Oscillation has been argued to exert influence over the ice regime in the Northern Hemisphere (Robertson et al., 2000). The so-called positive phases of NAO (associated with strong westerly winds and increased flow of warm and moist air to Western Europe) cause warmer winters, their later start and early springs (Chen and Hellström, 1999; Paeth et al., 1999). Changes in air temperature and in the occurrence of rainfalls influenced by airflow from the North Atlantic (indicated by NAO) sig- nificantly affect the ice regime (Loewe and Koslowski, 1998). In addition, a major factor possibly affecting the ice regime is global warming (Morse and Hicks, 2005; Lind et al., 2016). The records made during the last two centuries on ice break-up dates on rivers in the Northern Hemisphere provide consistent evidence of later freezing and earlier break-up (Magnuson et al., 2000). Several studies have analysed ice regime trends for inland waters (Beltaos, 1997; Benson et al., 2000; Hodgkins et al., 2002). Such studies are facilitated by the fact that easily identifiable parameters describing ice break-up have been recorded for a long period of time. These studies have clearly shown long-term changes in climate and have also argued that natural processes and the ice regime in Northern Europe are related to changes in NAO (Yoo and D'Odorico, 2002). The ice conditions of the Baltic Sea have been previously studied using a historical time series of ice break-up at the port of Rìga (Jevrejeva, 2001) and along the coastline of Estonia (Sooaar and Jaagus, 2007). However, the ice regime of inland waters in Latvia, especially in association with changes of the regime in coastal waters, has not been studied, and the factors affecting major fluctuations of the ice regime have not been identified.

The aim of this study was to determine the character of long-term changes of the sea ice regime along the coastline of Latvia, in relation to long-term climate change (temperature) and large-scale atmospheric circulation processes (the North Atlantic Oscillation, NAO). 


\section{DATA SOURCES AND METHODS}

Data on ice regime (formation of permanent ice cover, ice break-up, and calculated length of ice cover) were extracted from bulletins of hydrological observations (1925-2013) at the Latvian Centre of Environment, Geology, and Meteorology. The time series of the River Daugava ice break-up dates were first published by P. Stakle (1931). Air temperature records at the Riga-University Meteorological Station were obtained for the period from 1795 to 2013. During the studied period (1925-2013), the sampling and observation methods followed standard approaches and historical observations were re-evaluated to adjust them to the existing principles of time measurement (Stakle, 1931). This study used only observation data, and no data were substituted. The locations of sampling sites and regular monitoring stations are shown in Figure 1.

To determine relationship to wide-scale climatic forcing factors, we used the extended North Atlantic Oscillation (NAO) index (Luterbacker et al., 2002). The NAO index data are classified in three categories: high (NAO 1) strong westerly, normal (NAO 1) and low (NAO -1) weak westerly. To identify climatic turning points, the recently suggested Baltic winter index (WIBIX) (Hagen and Feistel, 2005) was used. This derived climate index is based on monthly values of the first principal components of: a) winter anomalies (January - March) of air pressure difference between Gibraltar and Reykjavik to describe the North Atlantic Oscillation, b) sea level anomalies of Landsort (Sweden) to characterise the filling level in the Baltic Proper, and c) maximum Baltic ice cover, to include the influence of continentally dominated alignments of atmospheric centres in action. The resulting time coefficients are regressively computed by corresponding winter anomalies in air temperature over central England. Severe (continental, WIBIX < 0) and mild (maritime, WIBIX > 0) winter types alternate, and the associated turning points characterise climate regime shifts.

The non-parametric Mann-Kendall test for monotone trends in time series of data grouped by sites, plots and seasons was chosen for determination of trends, as this is a relatively robust method concerning missing data and has no

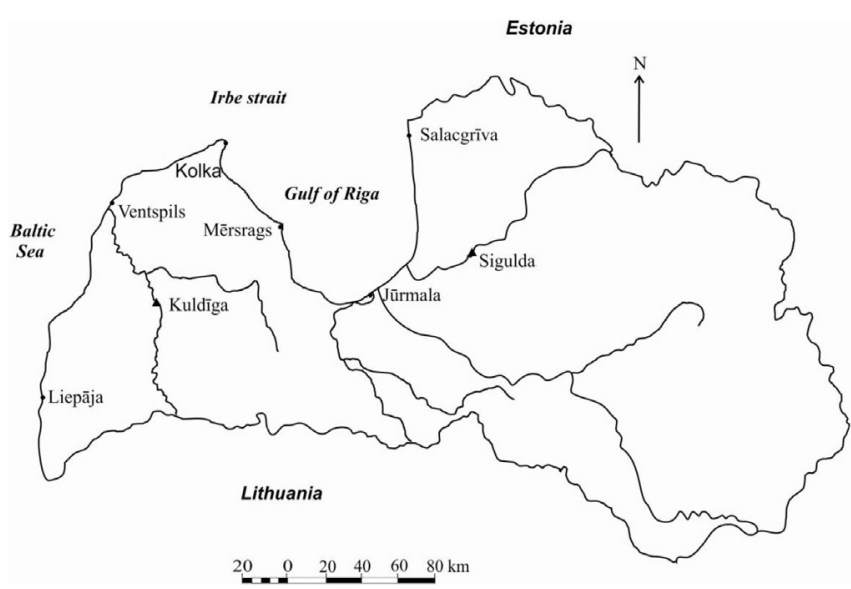

Fig. 1. Locations of stations for observation of sea ice $(\bullet)(1949-2013)$ and inland ice (A) (1949-1999) regimes in Latvia.

strict requirements regarding data heteroscedasticity. The Mann-Kendall test was applied separately to each variable at each site at a significance level of $p<0.05$. A trend was considered as statistically significant at the $5 \%$ level if the test statistic was greater than 2 or less than -2 . The COND/MULTIMK code (Libiseller and Grimvall, 2002) was used for trend analysis.

\section{RESULTS}

The beginning of ice formation. Ice development begins in Pärnu Bay, where the first new ice formation occurs in the middle of December (Table 1). Thereafter, the ice-covered area extends along the north-eastern coast of the Gulf of Riga. In mid-January, its width is 5 to 6 nautical miles on average. At the same time, new ice formations near the southern and western coasts of the gulf occur.

The most intensive ice development occurs in February, when, under favourable conditions, the Gulf of Riga becomes completely ice-covered. In the middle of the month, the pack ice brought by currents freezes and covers Irbe Strait with rigid and ridged ice. At the same time, the width and thickness of the fast ice increases along the rest of the gulf coastline, and various ice forms intensively develop

Table 1

BASIC CHARACTERISTICS AND ICE REGIME OF THE STUDY SITES IN LATVIA AND ITS COASTLINE

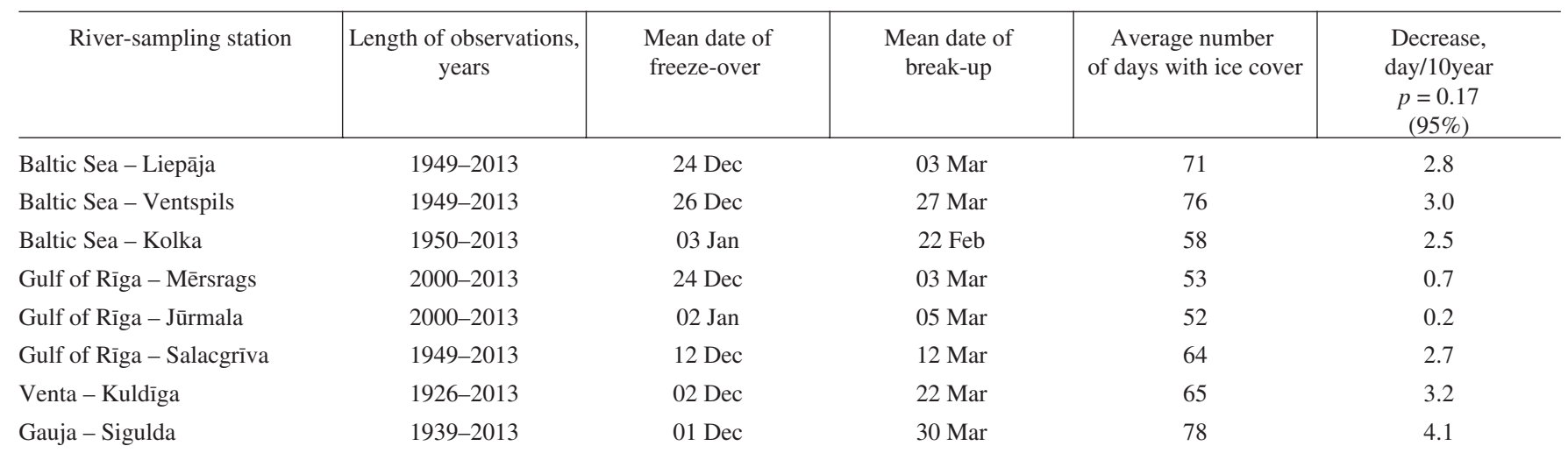


also in the central part of the gulf. In moderate winters, the Gulf of Riga and Irbe Strait become completely ice-covered by the end of the month. However, during severely cold winters, a solid and rigid ice cover over the Gulf of Riga may form already in the middle of January, whereas in mild winters, the gulf may remain mostly ice-free throughout the winter season.

The development of pack ice usually begins in coastal waters and extends in parallel to isobaths. However, its development is uneven, reflecting alterations of the cold and warm spells. The pack ice maximum occurs in late February to early March, and, during moderate and severe winters, pack ice completely covers both the Gulf of Riga and Irbe Strait.

During winters, the surface water is cooled so much that ice may form also at the coastline of the Baltic Sea. However, the expansion of ice varies widely from year to year, depending on whether the weather is mild or cold. The water territories concerned are mostly ice-free and are covered with ice only during the most severe winters. However, the ice is mostly thin and fragile, and, if the wind direction is favourable, the ice rapidly floats from the shore into the open sea. In the coastal waters of the Baltic Sea, the ice development begins at the end of December, sometimes in the middle of November.

The disappearance of ice. With the prevailing westerly winds, the ice break-up begins in the western part of the Gulf of Riga and gradually progresses to the east. The first area of the gulf to become ice-free is Irbe Strait, followed by the western and southern parts of the Gulf. In the north and north-eastern areas, in turn, the melting and rotten pack ice remains for the longest periods.

During late and cold springs, there can be some differences in the disappearance of ice: at first, the ice disappears in the comparatively shallow north-eastern part of the Gulf of Riga, as the water temperature begins to rise due to the river inflow. In this case, the pack ice remains in the central part of the gulf for longer.

The length of the ice season. The average length of the ice season is the longest in Pärnu Bay and in the northern part of the Gulf of Riga, where it is 145 days or almost five months. The shortest ice season of two months is characteristic of the south-western part of the Gulf of Riga, Irbe Strait and near the Latvian coast of the Baltic Sea. In the southern part of the gulf, as well as in the area near Kolka, the average ice season is two to three months long. The maximum observed ice season length in the Gulf of Riga is 168 days, and in the coastal waters of the Baltic Sea - 127 days. The most severe winter during the observation period was in 1941/1942. During this winter, the maximum ice cover at the coastline of the Baltic Sea was observed at the end of March to beginning of April, with ice thickness of about $60 \mathrm{~cm}$. The ice thickness was $55.7 \mathrm{~cm}, 6.4 \mathrm{~km}$ from the coast near Liepāja and $48.6 \mathrm{~cm}$ at distance $14.5 \mathrm{~km}$ from Ventspils.
Changes in the length of the ice season at the coastline of Latvia. The ice conditions are observed in six marine observation stations in Latvia (Fig. 1). The stations of Ventspils and Liepāja, which are situated east of the central part of the Baltic Sea, represent the ice conditions characteristic for the open part of the sea, where usually the concentration of ice is the smallest and the length of the ice season - the shortest. The Kolka station represents ice conditions in the shallow Irbe Strait, and the Mērsrags station represents conditions of the western part of the gulf. These two stations are situated in an area of comparatively rapid changes in the concentration of ice, as the ice tends to break up and drift to the east with the prevailing westerly winds, forming ice-free areas. The Jūrmala observation station represents the shallow southern coast of the gulf. The Salacgrivva station represents the north-eastern part of the gulf, where ice expansion usually is the greatest and the ice season is the longest.

During the past $\sim 150$ years, there has been a significant increasing trend in the values of air temperature, which is even more obvious during winter seasons (Klavins et al. 2002). The changes in air temperature have also led to significant changes in ice conditions both at the Latvian coastline of the Baltic Sea and in the Gulf of Riga (Jevrejeva, 2001). A significant decreasing tendency of the length of ice season for the period of 1949-2013 was observed (Table 2) at the coastline of the Baltic Sea (Fig. 2), and even a more significant decreasing trend was observed in the Gulf of Riga (Fig. 3).

Ice conditions during the first decade of the $21^{\text {st }}$ century (2001-2011). Although the length of ice season has significantly decreased over a longer period (Gebre et al., 2014), during the past decade, there still have been some winters with substantial ice cover over the coastal waters of Latvia (for example, in winter 2012/2013). The total number of days with ice cover for the past ten years remains rather high: from 452-491 days at the coastline of the Baltic Sea up to 677-757 days in the Gulf of Riga (Fig. 4), with average annual ice season length of 45-49 and 68-76 days, respectively. During the past decade, the mildest winters with the lowest abundance of ice cover were in winters of 2001/2002, 2006/2007 and 2008/2009, when the development of sea ice was of a short range and present only in some areas of the coastal waters. In contrast, the winters of

Table 2

LONG TERM TRENDS OF ICE COVER DURATION ACCORDING TO THE MANN-KENDALL NORMALISED TEST STATISTICS

\begin{tabular}{lcc|c}
\hline \multicolumn{1}{c|}{ River-sampling station } & $\begin{array}{c}\text { Period of } \\
\text { observation }\end{array}$ & $\begin{array}{c}\text { Normalised } \\
\text { test statistic }\end{array}$ & $\begin{array}{c}p \text {-value } \\
\text { (one-sided test) }\end{array}$ \\
\hline Baltic Sea - Liepāja & $1949-2013$ & -2.61 & 0.009 \\
Baltic Sea - Ventspils & $1949-2013$ & -3.34 & 0.009 \\
Baltic Sea - Kolka & $1950-2013$ & -2.85 & 0.014 \\
Gulf of Rīga - Salacgrīva & $1949-2013$ & -4.42 & 0.001 \\
Venta - Kuldīga & $1926-2013$ & -1.21 & 0.113 \\
Gauja - Sigulda & $1939-2013$ & -2.87 & 0.002
\end{tabular}




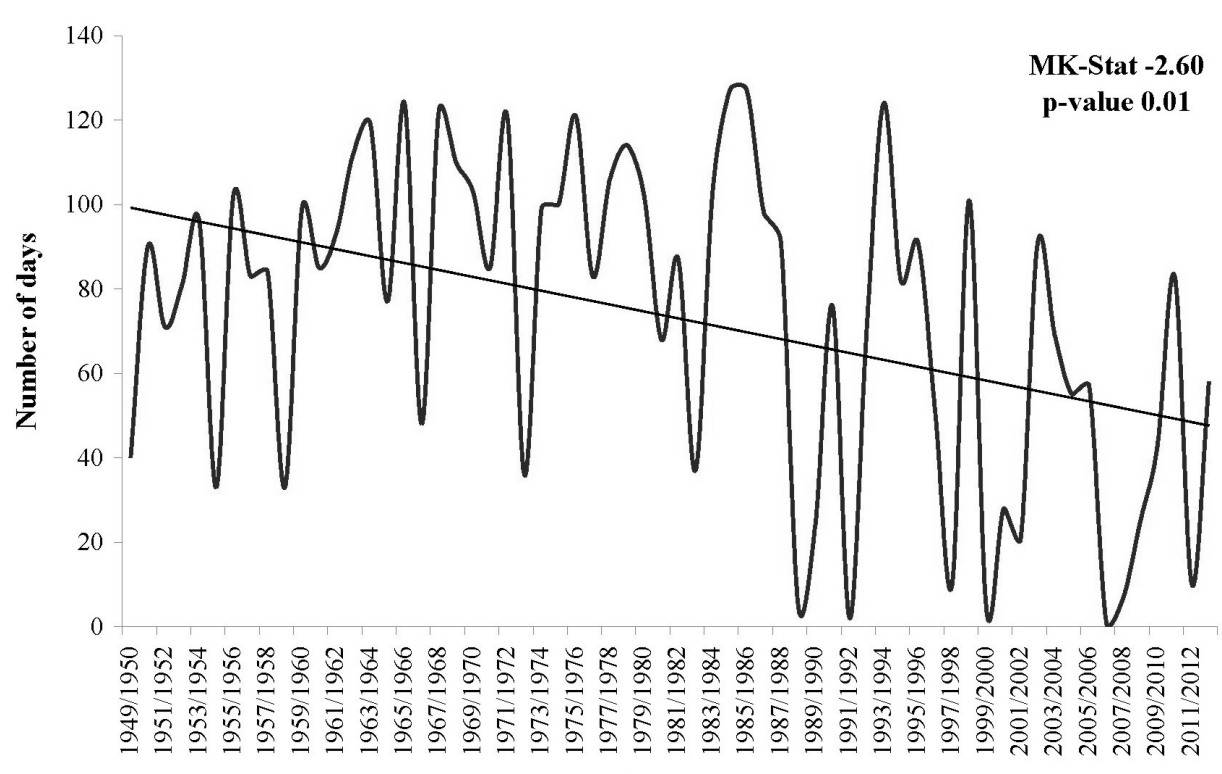

Season

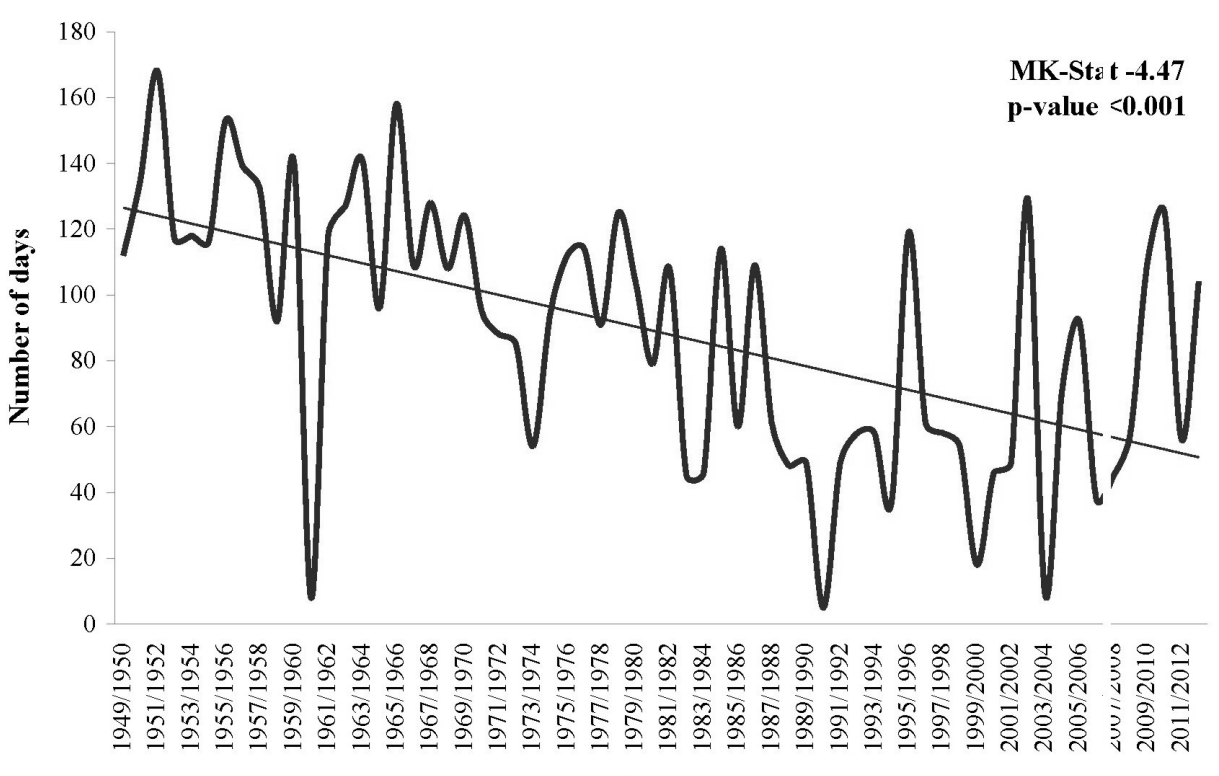

Fig. 2. Trend in the length of ice season in the coastal areas of the Baltic Sea (Liepāja) for the period of 1949-2013.

\section{Season}

Fig. 3. Trend in the length of ice season in the coastal areas of the Gulf of Riga (Salacgrīva) for the period of 1949-2013.
2002/2003, 2010/2011 and 2012/2013 were the most severe during the past decade.

During the winter of 2010/2011, the cold spell lasted for a long period of time. In many observation stations of Latvia, the minimum temperature records were broken. The development of ice occurred rapidly, and the Gulf of Riga was completely ice-covered already by the middle of February (Fig. 5).

The changes in the duration of ice cover can be strongly associated with the changes in its formation time. In the last decades, a stable ice cover (except in severely cold winters) appeared later (Fig. 6) and melted earlier (Fig. 7).

\section{DISCUSSION}

A comparison of the ice regime on Latvian inland rivers and the ice regime along the coastline of Latvia (Figs. 8, 9) indi- cates that it is longer on inland water bodies, but these values are significantly correlated. However, in case of rivers, processes in their basins also play an important role, and, therefore, the correlations are far from $100 \%$.

During the last decades, a significant increase in air temperature has been recorded in the Baltic region and Latvia. The seasonal air temperatures, according to the records of the Rìga-University meteorological station, have changed substantially over the last 200 years (1795-2013). The annual mean temperature has increased by $1.1{ }^{\circ} \mathrm{C}$, and the trend is significant (test statistic 4.37; $p=0.0000$ ). However, the increase in temperature has not been similar among seasons. The highest increase in air temperature was observed for spring $\left(2.1{ }^{\circ} \mathrm{C}\right.$, test statistic 5.18; $\left.p=0.000\right)$ and winter $\left(1.9{ }^{\circ} \mathrm{C}\right.$, test statistic $\left.2.77 ; p=0.0028\right)$ seasons. A smaller increase in temperature (by $0.5{ }^{\circ} \mathrm{C}$, test statistic $1.81 ; p=$ 0.03 ) was typical for the autumn season. There was no trend observed for summer temperatures covering the entire pe- 


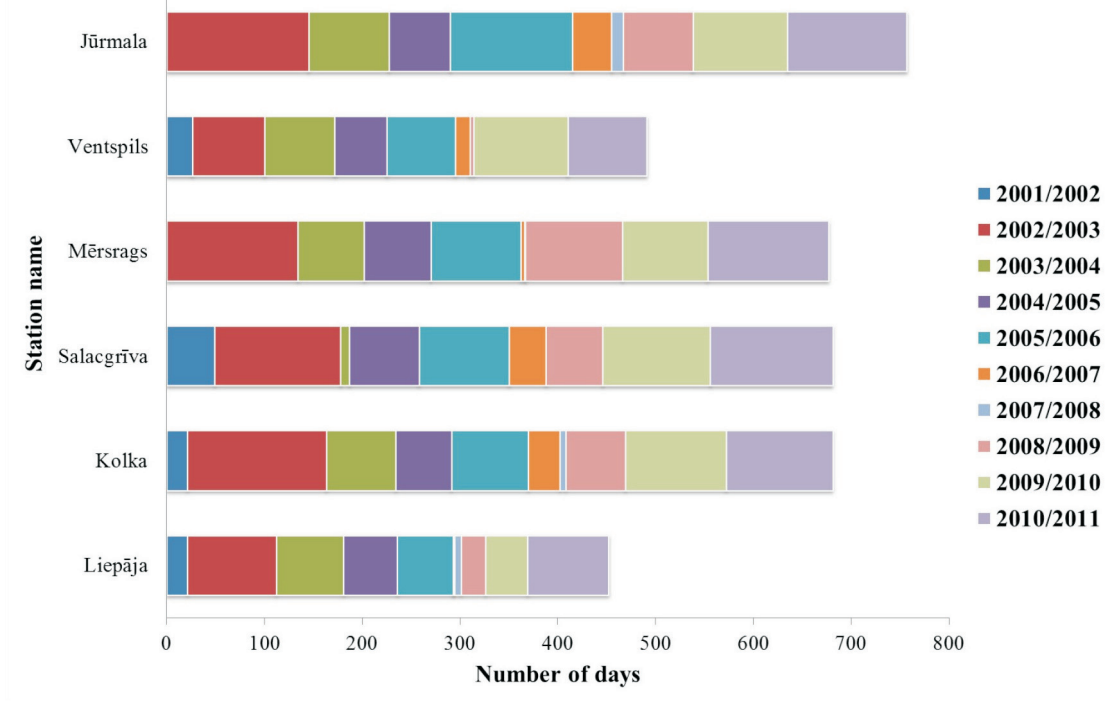

Fig. 4. Annual and total lengths of ice season at six marine observation stations of Latvia for the period of 2001-2013.

riod from 1795 to 2002. Compared to the 30-year mean (1961-1990), the lowest mean temperature occurred for annual and seasonal temperatures (autumn, spring and summer) during the period from 1830 to 1930 . Winter season temperatures have been increasing gradually since the $19^{\text {th }}$ century, and the long-term minimum was not reached during the 1830-1930 period. Notable increases in winter and spring air temperatures have been observed since the 1970s (Lizuma et al., 2007).

Furthermore, not only air temperature but also water temperature in the Baltic Sea and the Gulf of Riga has increased significantly (Fig. 10), evidently affecting the sea ice regime. Similar trends have been found at all studied stations for changes in both maximal and minimal water temperatures, especially for changes in water temperatures in the autumn (September, October, November) and winter seasons (December, January, February).

Processes over the North Atlantic appear to have a significant influence on the climate in the Baltic region, especially during winter (December, January, and February) and cold seasons (October-April) (Figs. 11, 12).

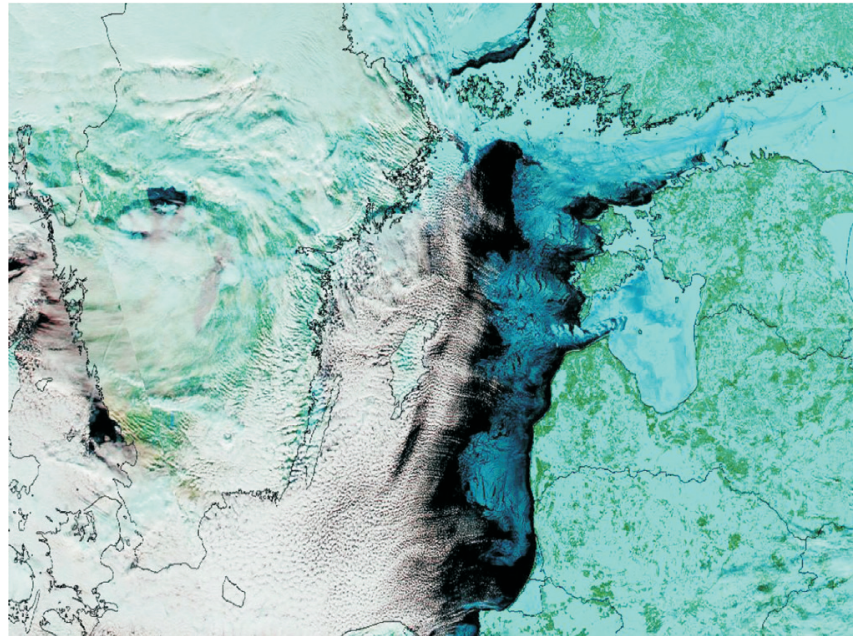

Fig. 5. Ice conditions in the coastal areas of Latvia on 21 February 2011 (MODIS Aqua image; channel combination 7-2-1; spatial resolution $1 \mathrm{~km})$.

Figures 11 and 12 depict the winter period series of the NAO index during the second half of the $20^{\text {th }}$ century and the number of days with ice cover. A strong negative correlation between the NAO index and the number of days with

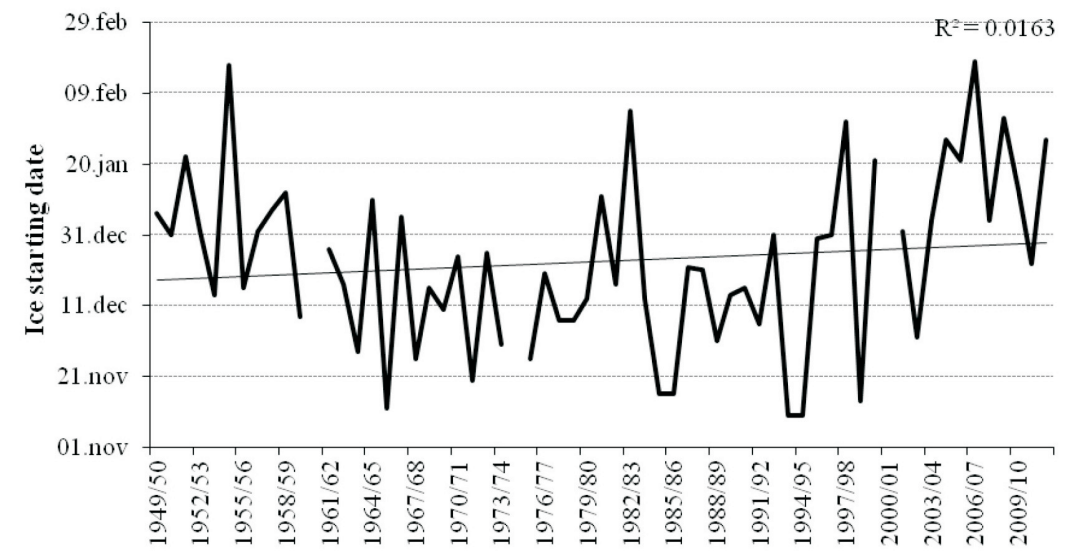

Fig. 6. Long-term changes in the starting date of ice cover appearance at Liepāja. 

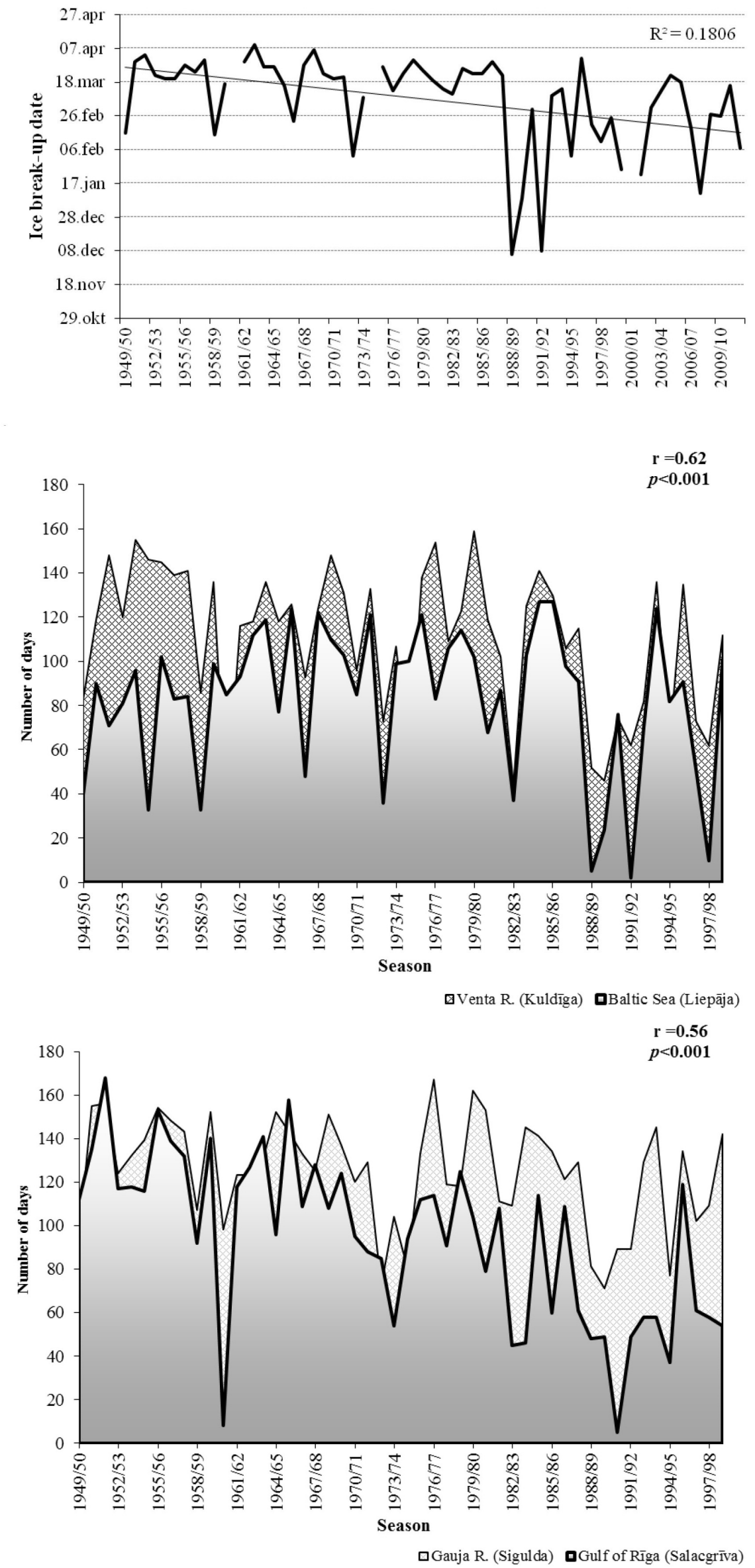

Fig. 7. Long-term changes in the break-up date of ice cover at Liepāja.

Fig. 8. Correlation of the duration of ice cover in a coastal zone of the Baltic Sea (at Liepāja)
Fig. 9. Correlation of the duration of ice cover in a coastal zone of the Gulf of Riga (at Salacgrīva) and the River Gauja (Sigulda). 


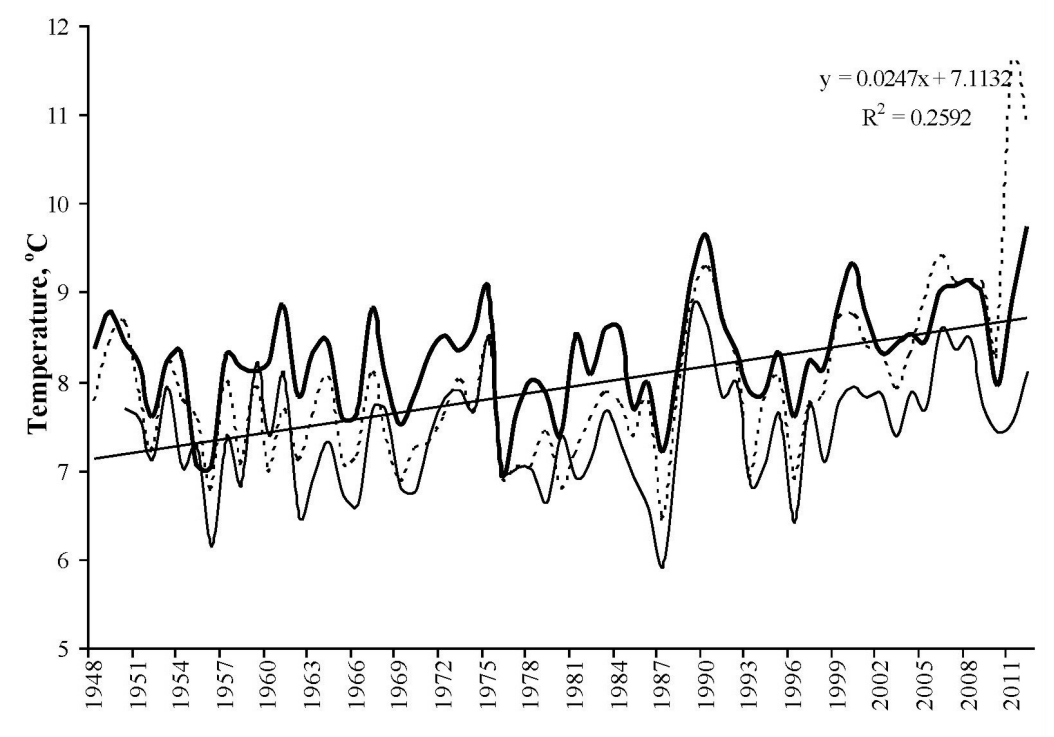

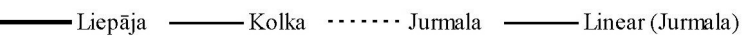
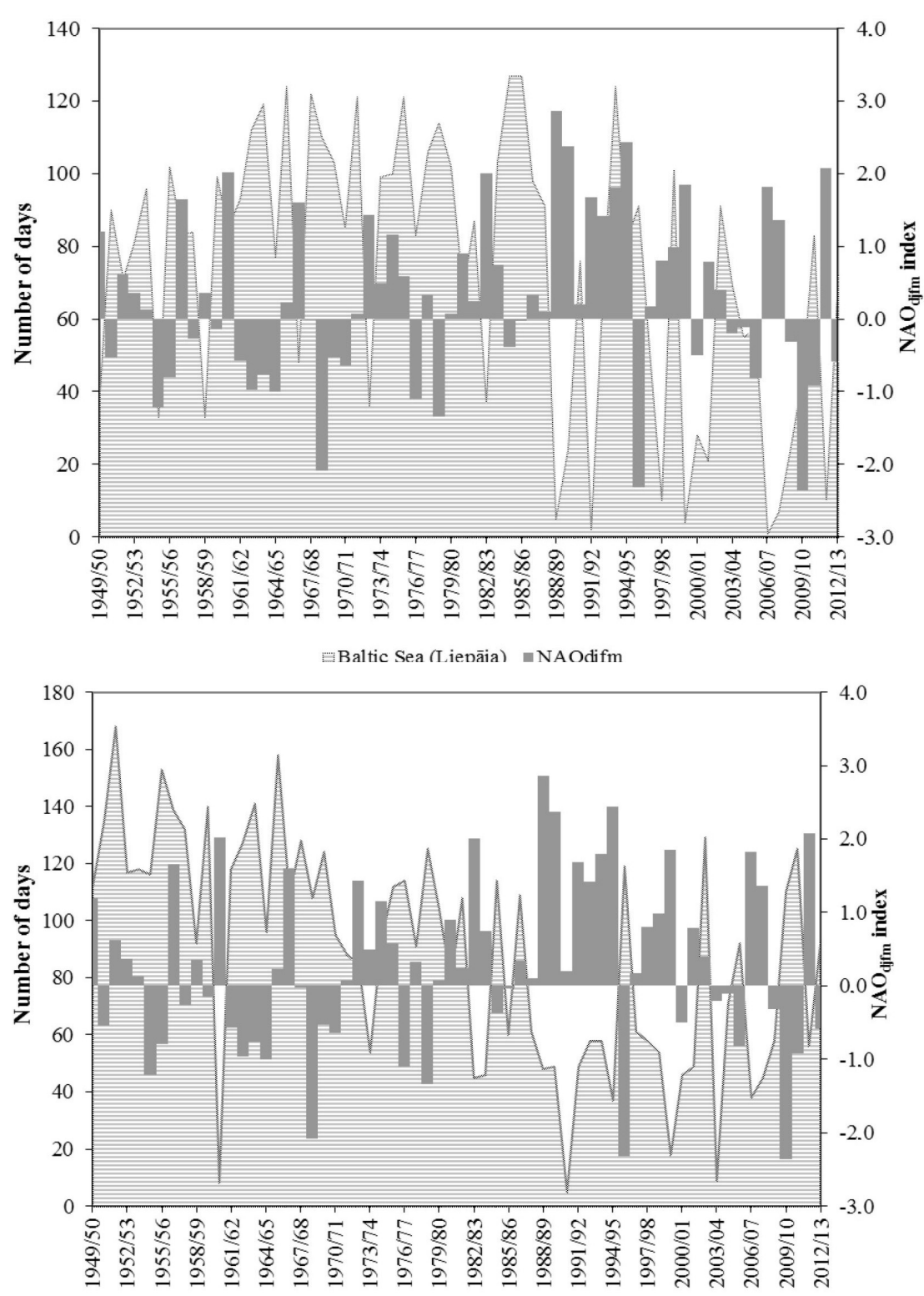

EGulf of Rīga (Salacgrīia) $\quad$ NAOdjfm
Fig. 10. Changes in the annual average water temperature at Liepāja, Kolka, and Jūrmala.

Fig. 11. Correlation $(\mathrm{r}=-0.44, p 0.001)$ between the prolongation of ice cover duration on the Baltic Sea at the coastline of Latvia (Liepāja) and the NAO winter index.

Fig. 12. Correlation $(\mathrm{r}=-0.51, p 0.001)$ between the prolongation of ice cover on the Gulf of Riga at the coastline of Latvia (Salacgrīva) and the NAO winter index. 


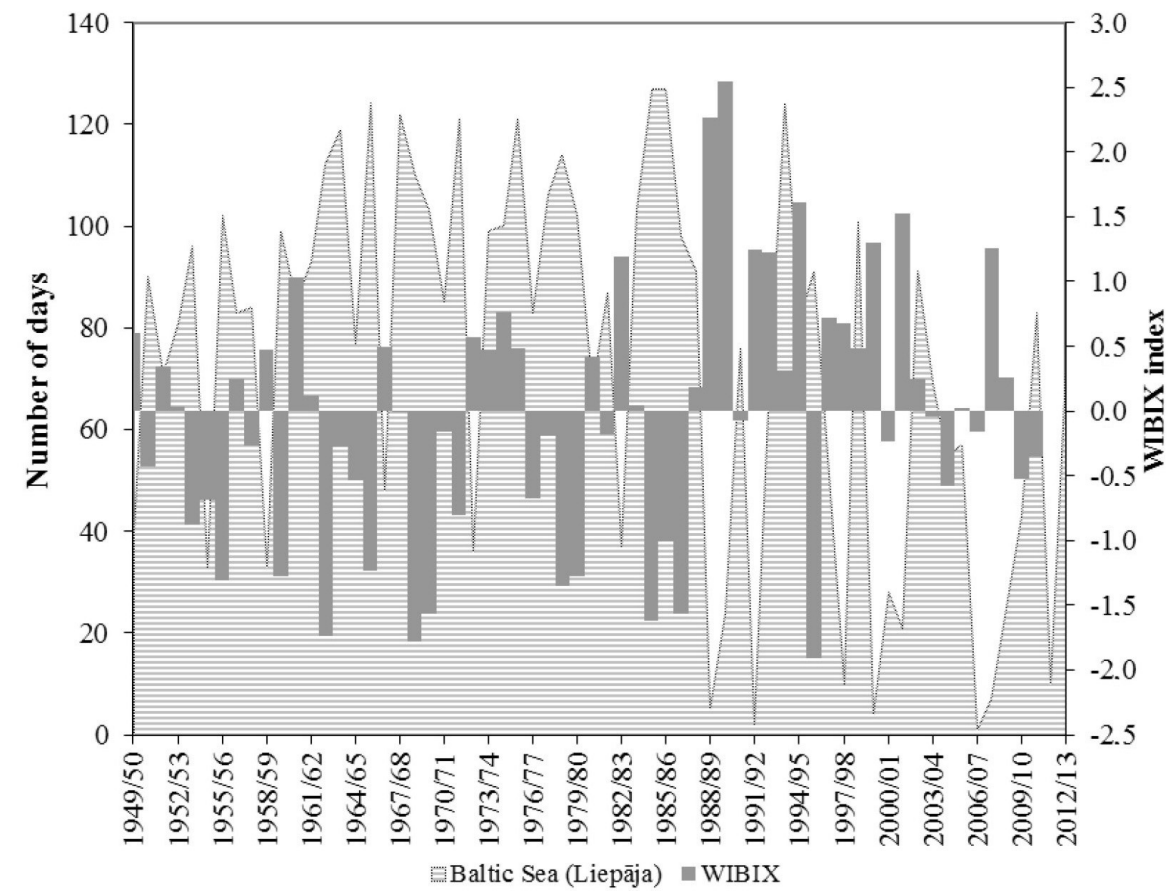

Fig. 13. Correlation $(\mathrm{r}=-0.64, p<0.001)$ between the prolongation of ice cover on the Baltic Sea at the coastline of Latvia (Liepāja) and the WIBIX index. ice cover along the coastline of Latvia exists, indicating that large-scale atmospheric circulation processes over the North Atlantic greatly influence the winter climate in the Baltic region. NAO has been observed to influence winter precipitation with varying intensity along the Norwegian coast, in northern Sweden and in southern Finland, where terrain plays an important role (Uvo, 2003). The strong correlation found in our study highlights the fine linkages between the large-scale NAO forcing factors and the regional scale climate processes in the Baltic region. Moreover, the negative correlation between winter temperatures and NAO indexes has become stronger during the last 100 years (Marshall et al., 2001; Hagen and Feistel, 2005; de Rham et al., 2008). Changes in ice regime can also be directly related to the recently suggested (Hagen and Feistel, 2005) derived Baltic winter climate index (WIBIX) (Fig. 13), which is better correlated with the parameters describing ice regime than the NAO winter index.

A strong negative correlation between the NAO index, the WIBIX index and the ice-break up events shows that processes over the North Atlantic are the driving force for the sea ice regime at the coastline of Latvia. In winter, an intense westerly circulation moves fronts and air masses through the mid-latitudes, while it weakens considerably during the warm period, and the majority of precipitation events occur due to different processes.

\section{CONCLUSIONS}

The duration of ice cover on the Baltic Sea and the Gulf of Riga has been decreasing during the last 60 years and is related to later start and earlier melt of the ice cover. There are significant differences in respect to ice cover in the Gulf of Riga and at the coastline of the Baltic Sea. The time of ice break-up depends on global climate change and can be related to increasing air and sea water temperatures. However, the trends of sea ice regime are not consistent over different periods, and there are also alternating mild and severe winters. The sea ice regime appears to be greatly influenced by large-scale atmospheric circulation processes over the North Atlantic.

\section{ACKNOWLEDGEMENTS}

The financial support from the grant No. 526/2012 of the Latvian Council of Science is acknowledged.

\section{REFERENCES}

Beltaos, S. (1997). Onset of river ice breakup. Cold Region Sci. Technol., 25 , 183-196.

Beltaos, S., Burrell, B. C. (2003). Climatic change and river ice breakup. Can. J. Civil. Eng., 30 (1), 145-155.

Benson, B. J., Magnson, J. J, Jacob, R. L., Fuenger, S. L. (2000). Response of lake ice breakup in the Northern hemisphere to the 1976 interdecadal shift in the North Pacific. Verh. Internat. Verein Limnol., 27, 2770-2774.

Chen, D., Hellström, C. (1999). The influence of the North Atlantic Oscillation on the regional temperature variability in Sweden: Spatial and temporal variations. Tellus, 51A, 505-516.

Gebre, S., Boissy, T., Alfredsen, K. (2014). Sensitivity to climate change of the thermal structure and ice cover regime of three hydropower reservoirs J. Hydrol., $\mathbf{5 1 0}$ (3), 208-227.

Granskog, M., Kaartokallio, H., Kuosa, H., Thomas, D. N., Vainia, J. (2006). Sea ice in the Baltic Sea. Estuar. Coast. Shelf. Sci., 70, 145-160.

Hagen, E., Feistel, R. (2005). Climatic turning pints and regime shifts in the Baltic Sea region: The Baltic winter index (WIBIX) 1659-2002. Boreal Environ. Res., 10, 211-224.

Hurrell, J. W., van Loon H. (1997). Decadal variations in climate associated with the North Atlantic Oscillation. Clim. Change, 36, 301-326.

Hodgkins, G. A., James, I. C., Huntington, T. G. (2002). Historical changes in lake ice-out dates as indicators of climate change in New England, 1850-2000. Int. J. Climatol., 22, 1819-1827. 
Jevrejeva, S. (2001). Severity of winter seasons in the northern Baltic Sea between 1529-1990: Reconstruction and analysis. Clim. Res., 17, 55-62.

Johannessen, O. M., Bengtsson, L., Miles, M. W., Kuzmina, S. I., Semenov, V. A., Alekseev, G. A., Nagurnyi, A. P., Zakharov, V. F., Bobylev, L. P., Petterson, L. H., Hasselman, K., Cattle, H. P. (2004). Arctic climate change: Observed and modelled temperature and sea-ice variability. Tellus, 56A, 329-341.

Klavins, M., Briede, A., Rodinov, V., Kokorite, I., Frisk, T. (2002). Long-term changes of the river runoff in Latvia. Boreal Environ. Res., 7, $447-456$.

Libiseller, C., Grimvall, A. (2002). Performance of partial Mann-Kendall tests for trend detection in presence of covariates. Environmetrics, 13, 71-84.

Laidre, K. L., Jorgensen, M. P. H. (2005). Arctic sea ice trends and narwhal vulnerability. Biol. Conserv., 121, 509-517.

Lind, L., Alfredsen, K., Kuglerová, L., Nilsson C. (2016). Hydrological and thermal controls of ice formation in 25 boreal stream reaches $J$. Hydrol., 540 (11), 797-811.

Loewe, P., Koslowski, G. (1998). The Western Baltic sea ice season in terms of a mass-related severity index 1879-1992 (II) spectral characteristics and association with the NAO, QBO, and solar cycle. Tellus, 50 (A), 219-241.

Lizuma, L., Klavins, M., Briede, A., Rodinovs, V. (2007). Long-term changes of air temperature in Latvia. In: Climate Change in Latvia. Ed. M. Klavins. UL Publishing House, Rìga, pp. 11-21.

Magnuson, J. J., Robertson, D. M., Benson, B. J., Wynne, R. H., Livingstone, D. M., Arai, T., Assel, R. A., Barry, R. G., Card, V., Kuusisto, E., Granin, N. G., Prowse, T. D., Stewart, T. D., Vuglinski, V. S. (2000). Historical trends in lake and river ice cover in the Northern hemisphere. Science, 289, 1743-1746.

Marshall, J., Kushnir, Y., Battisti, D., Chang, P., Czaja, A., Dickson, R., Hurrell, J., McCartney, M., Saravanan, R., Visbeck, M. (2001). North Atlantic climate variability: Phenomena, impacts and mechanisms. Int. J. Climatol., 21, 1863-1898.

Received 13 February 2014
Morse, B., Hicks, F. (2005). Advances in river ice hydrology 1999-2003. Hydrol, Proc., 19 (1), 247-263.

Osborn, T. J., Briffa, K. R., Tett, S. F. B., Jones, P. D., Trigo, R. M. (1999). Evaluation of the North Atlantic Oscillation as simulated by a coupled climate model. Clim. Dynamics, 15, 685-702.

Paeth, H., Hense, A., Glowienka-Hense, R., Voss, R., Cubash, U. (1999). The North Atlantic Oscillation as an indicator for greenhouse-gas induced regional climate change. Clim. Dynamics, 15, 953-960.

de Rham, L. P., Prowse, T. D., Bonsal, B. R. (2008). Temporal variations in river-ice break-up over the Mackenzie River Basin, Canada. J. Hydrol., 349, 441-454.

Robertson, D. M., Wynne, R. H., Chang, W. Y. B. (2000). Influence of El Nińo on lake and river ice cover in the Northern hemisphere from 1900 to 1995. Verh. Internat. Verein Limnol., 27, 2784-2788.

Sarauskiene, D., Jurgelenaite, A. (2008). Impact of climate change on river ice phenology in Lithuania. Environ. Res. Eng. Manag., 4 (46), 13-22.

Saucier, F. J., Semeville, S., Prinsenberg, S., Roy, F., Smith, G., Gachon, P., Caya, D., Laprise, R. (2004). Modelling the sea ice-ocean seasonal cycle in Hudson Bay, Foxe basin and Hudson strait, Canada. Clim. Dynam., 23, 303-326.

Sooaar, J., Jaagus, J. (2007). Long-term changes in the sea ice regime in the Baltic Sea near the Estonian coast. Proc. Estonian. Acad. Sci. Eng., 13 (3), 189-200.

Stakle, P. (1931). Hidrometriskie novērojumi Latvijā līdz 31.X1929 [hydrometric observations in Latvia until 31.10.1929]. Finanšu ministrijas Jūrniecības departaments. Rīga, 374 lpp. (in Latvian).

Takics, K., Kern, Z. (2015). Multidecadal changes in the river ice regime of the lower course of the River Drava since AD 1875 J. Hydrol., 529 (3), 1890-1900.

Uvo, C. B. (2003). Analyses and regionalization of Northern Europe winter precipitation based on its relationship with North Atlantic Oscillations. Int. J. Climatol., 23, 1185-1194.

Yoo, J. C., D’Odorico, P. (2002). Trends and fluctuations in the dates of ice break-up of lakes and rivers in Northern Europe: the effect of the North Atlantic Oscillation. J. Hydrol., 268, 100-112.

\section{LATVIJAS IEKŠZEMES UN PIEKRASTES ŪDEṆU LEDUS REŽĪMA DINAMIKA UN TO IETEKMĒJOŠIE FAKTORI}

Jūru ledus režīms uzskatāms par klimata pārmaiṇu jutīgu indikatoru. Pētījuma mērkis ir analizēt Latvijas piekrastes un Rīgas līča ledus režīmu, salīdzinot to ar iekšzemes ūdeṇiem. Latvijas iekšzemes un piekrastes ūdeṇu ledus režīms uzrāda globālās sasilšanas ietekmes, un tā pārmaiṇas ir saistāmas ar gaisa un jūras ūdens temperatūras izmaiṇām. Latvijas iekšzemes un piekrastes ūdeṇu ledstāves ilgums pēdējās desmitgadēs ir samazinājies, bet vienlaikus iezīmējas klimatisko pārmaiṇu periodiskuma ietekme. Ledus režīmu raksturo gan maigu, gan aukstu ziemu periodiska nomaiņa, un to ietekmē liela mēroga atmosfēras cirkulācijas procesi virs Atlantijas okeāna, ko pierāda cieša korelācija ar Ziemeḷatlantijas oscilācijas indeksu. 